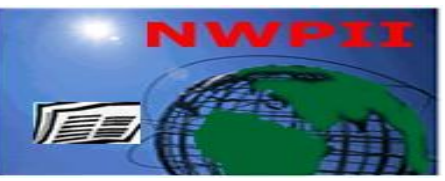

American Journal of Biomedical Sciences

ISSN: 1937-9080

nwpii.com/ajbms

\title{
Carbenoxolone Exerts Neuroprotection in an Animal Model of Parkinson's Disease Induced by Proteasome Inhibitor MG-132
}

\author{
Ankita Bhardwaj" Poonam Thakur", Bimla Nehru* \\ Department of Biophysics, Panjab University, Chandigarh-160014, India \\ \# contributed equally to work \\ * Corresponding author \\ Dr. Bimla Nehru \\ Department of Biophysics \\ Panjab University \\ Chandigarh-160014 \\ India \\ Phone: +91 01722534128 \\ Email: bnehru@pu.ac.in
}

Received: 7 May 2014; | Revised:27 September 2014; | Accepted: 9 October 2014

\begin{abstract}
Dysfunctions of ubiquitin proteasome system (UPS), intracellular protein degradation mechanism lead to the aggregation of aberrant proteins, which is a hallmark of Parkinson's disease (PD). Heat shock proteins (HSP) assist in refolding of misfolded proteins and in proper functioning of UPS. Thus, the neuroprotective potentials of carbenoxolone (Cbx), a HSP inducer were evaluated in a PD model generated by a single intranigral injection of a proteasome inhibitor MG-132 into rat brains. Cbx $(20 \mathrm{mg} / \mathrm{kg}$ body weight $)$ was given as post-treatment for 12 days. MG-132 destroyed dopaminergic neurons causing loss of dopamine and tyrosine hydroxylase $(\mathrm{TH})$ that resulted in impaired motor functions. Elevations in the markers of oxidative stress like LPO (Lipid peroxidation), protein carbonyl, NO (Nitric oxide) and citrulline was also observed in MG-132 treated animals. However, induction of HSP-70 by Cbx helped to combat the toxicity caused by proteasome inhibition. Reduction in oxidative stress was also observed after Cbx co-treatment which helped in preventing neuronal cell death. As a result, improvements in the dopamine levels and associated motor functions were also observed. Thus, all the assessed parameters provide the clear evidence that $\mathrm{Cbx}$ is a potential neuroprotector for PD.
\end{abstract}

Keywords: UPS dysfunction; Carbenoxolone; Oxidative stress; Motor functions.

\section{Introduction}

Parkinson's disease (PD) is second most common age related neurodegenerative disorder that is highly prevalent in people over the age of 50 [1-2]. Pathologically, it is characterized by the specific loss of dopaminergic neurons within the substantia nigra region. The clinical symptoms include tremors at rest, rigidity, slowness or 
absence of voluntary movement, postural instability, and freezing [3]. Another crucial pathological hallmark of PD involves the accumulation of fibrous protein deposits known as Lewy bodies in the neuronal cytoplasm [4]. These deposits interfere with normal neuronal functions, protein-protein interactions and protein homeostasis [5].

Excessive free radical production and impaired anti-oxidant mechanism in the neurons lead to the protein modifications [6]. These alterations of cellular proteins cause them to transform into misfolded forms, which get accumulated in the neurons [7]. Usually the protein aggregation is rectified by the protective system of the cells known as ubiquitin proteasome system (UPS) [8-9]. However, during $\mathrm{PD}$, diminished expression of proteasome subunits and alterations in the proteasome subunits has been reported, which in turn inhibits its activity [10]. Due to the proteasome inhibition, fewer proteins are degraded in the proteasome core, which leads to the buildup of harmful crosslinked proteins and ultimately formation of Lewy bodies [11].

HSPs or molecular chaperones assist in folding and refolding of nascent polypeptide, or partially denatured proteins [12]. When moderately over-expressed in cells, HSPs exhibit beneficial effects in the pathological conditions associated with the protein misfolding and aggregation [12]. HSPs aid in the refolding of damaged and misfolded proteins and thus suppress their aggregation [13-15]. As a result, they exert cytoprotective action during proteotoxic stress [16-18].

Present study was designed with the aim to evaluate the beneficial effects of HSP induction in an animal model of PD. There are several type of HSP inducers reported in the literature, which include non-steroidal anti-inflammatory drugs, HSP-90 inhibitors, prostaglandins, anti-ulcer drugs, and some herbal medicines [19-21]. Carbenoxolone $(\mathrm{Cbx})$ is one such drug that acts as HSP inducer [22-24]. It has been reported to induce the heat shock protein-70 (HSP-70) [25], HSP-40 and HSP-27 [26]. Due to the central role of proteasome dysfunctions in PD pathogenesis, we used a semi-synthetic proteasome inhibitor
MG-132 to induce the toxicity in the nigral dopaminergic neurons in the male SD rats. In comparison to the other proteasome inhibitors such as lactacystin and bortezomib, MG-132 is a cheaper and a potent alternative proteasome inhibitor [27-28]. It effectively escalates the burden of misfolded proteins in the neurons and concomitantly increases the cellular stress [2932]. Hence, in the current study we evaluated the potential neuroprotective role of $\mathrm{Cbx}$ in rat model of PD induced by MG-132.

\section{Material and Methods}

\subsection{Experimental Animals}

Healthy male rats of the Sprague Dawley (SD) strain weighing between 200-250 grams and in the age group of 8-9 weeks were purchased from the Central animal house of Panjab University, Chandigarh. Animals were acclimatized in the department animal house for two weeks in polypropylene cages under hygienic conditions and were provided standard animal feed and water ad libitum throughout the treatment period. All procedures were done in accordance with the ethical guidelines for care and use of laboratory animals and were approved by Institutional Animal Ethics Committee (IAEC), Panjab University Chandigarh, India. The standard animal feed was obtained from Aashirwad industries, Punjab, India.

\subsection{Chemicals}

MG-132 was purchased from Calbiochem and Cbx was purchased from Sigma (St. Louis, MO). Chemicals for HPLC were procured from Merck. Other chemicals were procured from local suppliers (SRL, Hi-Media and CDH).

\subsection{Experimental design}

Animals are randomly allocated in four different groups (6-8 animals per group). Group 1 animals served as sham. They were unilaterally administered $2 \mu \mathrm{l}$ of DMSO dissolved in PBS (0.1 M, pH 7.0) into the substantia nigra. Group 2 animals were injected with MG-132 (0.01 mg in $2 \mu 1$ of DMSO dissolved in 0.1M PBS) into the substantia nigra. Group 3 animals were given a combined treatment of MG-132 as described 
before and followed by Cbx (20 mg/kg body weight i.p) administration for duration of 12 days. Group 4 animals were given $\mathrm{Cbx}$ alone. While the stereotaxic injection was given only once, Cbx treatment was given everyday for a period of 12 days. For the surgeries, rats were anesthetized with the combination of ketamine $(80 \mathrm{mg} / \mathrm{kg}$ body weight i.p) and xylazine $(20 \mathrm{mg} / \mathrm{kg}$ body weight i.p). The unilateral injection of either MG132 dissolved in DMSO or DMSO alone dissolved in $0.1 \mathrm{M}$ PBS into the substantia nigra (AP $4.01 \mathrm{~mm}$, ML $1.5 \mathrm{~mm}$, DV $7.7 \mathrm{~mm}$ ) was then given on the right side of the brain.

Various behavioral assessments were carried out at regular intervals during the study period. First behavioral assessments were carried out 2 days after the stereotaxic surgery of the animals, second behavioral 8 days after surgery and the last behavioral assessment was done 24 hour before the sacrifice of the animals i.e. on $11^{\text {th }}$ day. After the completion of 12 days, animals were sacrificed and midbrain dissected out for various studies.

\subsection{General observation of animals}

To study the possible outcomes of the drug treatments, general behavior of the animals such as dietary intake, general body activity, movements, lethargy, stiffness or rigidity was monitored. The mortality rate of the rats was also recorded.

\subsection{Behavioral analysis}

\subsubsection{Catalepsy (Bar Test)}

The bar test was used for measuring the rigidity in the rats [33]. In the bar test, rats were placed with both front paws on the horizontal bar which was $9 \mathrm{~cm}$ above and parallel from the base and time recorded with a stopwatch. Whenever the animals removed one paw off the bar, the time was noted. The maximum cut off for bar test was fixed at 180 seconds.

\subsubsection{Measurement of locomotor activity (Actophotometer)}

A computerized actophotometer was used to measure the total locomotor activity (ambulations and rearing) of the rats (IMCORP, India). An array of 16 infrared emitter/detector pairs measured animal activity along the single axis of motion and the digital data was displayed on the front panel meters as ambulatory movements. Rats were allowed to acclimatize in the observation chamber for a period of 5 minutes and thereafter activity was monitored continuously for a period of 5 minutes. Locomotion was expressed in terms of total photo beam counts per 5 minutes [34].

\subsubsection{Rotarod test}

Rota-rod test was used to evaluate the effects of drug treatments on the motor balance and coordination of the rats. All rats were given two initial training trials of $300 \mathrm{sec}$, approximately 10 min apart, to maintain posture on the rota-rod. Bar was $3 \mathrm{~cm}$ in diameter and rotation speed was fixed at 20 revolutions per minute. After the initial training trials, a baseline trial of $120 \mathrm{sec}$ was conducted. The time for which each animal remained on the rota-rod was recorded [35].

\subsection{Neurotransmitter analysis (HPLC)}

Biogenic amines (Dopamine, DOPAC, HVA) were estimated by HPLC by the method of Thakur and Nehru [36]. Analysis was done by using Waters HPLC system equipped with ECD on a $\mathrm{C} 18$ reverse phase column. Data was recorded and analyzed with the help of Empower software. Mobile phase consisting of $32 \mathrm{mM}$ $\mathrm{NaH}_{2} \mathrm{PO}_{4}, 10 \mathrm{mM}$ sodium citrate, $0.025 \mathrm{mM}$ EDTA and $0.77 \mathrm{mM}$ 1-heptane-sulphonic acid was used and $\mathrm{pH}$ of the mobile phase was adjusted to 4.5 with the help of acetic acid. Electrochemical conditions for the experiment were set at $+0.800 \mathrm{~V}$, with the sensitivity range of 5-50 nA. Separation was carried out at a flow rate of $0.80 \mathrm{ml} / \mathrm{min}$.

$10 \%$ homogenates were prepared immediately before analysis in $0.1 \mathrm{M}$ perchloric acid and subjected to centrifugation for 20 minutes at $20,000 \mathrm{rpm}$. The supernatant was further filtered through $0.22 \mu \mathrm{m}$ nylon mesh and a volume of $20 \mu \mathrm{l}$ was injected into the column manually. Dopamine turnover was calculated by the formula DOAPC + HVA/Dopamine. All the chemicals used were of HPLC grade and procured from Merck, India. Standards for 
dopamine, DOPAC and HVA were procured from Sigma- Aldrich (St. Louis, MO, USA).

\subsection{Oxidative stress markers}

\subsubsection{Lipid peroxidation}

MDA is considered as the most informative marker of endogenous intoxication and reflects the degree of oxidative stress [37]. Lipid peroxidation was estimated by the method described by Wills [38]. $0.5 \mathrm{ml}$ of $10 \%$ tissue homogenate was added to $0.5 \mathrm{ml}$ Tris $\mathrm{HCl}$ buffer. It was incubated at $37^{\circ} \mathrm{C}$ for 2 hours and $1 \mathrm{ml}$ of cold TCA was added to the reaction mixture. Thereafter, samples were mix thoroughly and centrifuged at $800 \mathrm{~g}$ for $10 \mathrm{~min}$. Supernatant was boiled for $15 \mathrm{~min}$ with thiobarbituric acid (TBA). The MDA concentration was measured at $532 \mathrm{~nm}$ using an extinction coefficient $1.56 \times 10^{5} \mathrm{M}^{-1} \mathrm{~cm}^{-1}$. The results were expressed as nM MDA/ mg protein.

\subsubsection{Protein carbonyl}

It was estimated by method of Burcham [39] using DNPH-(2, 4 dinitrophenylehydrazine). 0.5 $\mathrm{ml}$ protein sample was added to reaction mixture containing $0.5 \mathrm{ml}$ of DNPH solution and $2 \mathrm{M}$ $\mathrm{HCl}$. For blank only $2 \mathrm{M} \mathrm{HCl}$ was added. Afterwards, the reaction was allowed to proceed at room temperature for 1 hour. Then $500 \mu \mathrm{l}$ of $20 \%$ TCA was added to the mixture and centrifuged for $3 \mathrm{~min}$. After discarding the supernatant, pellet was washed thrice with $1 \mathrm{ml}$ volumes of ethanol:ethyl acetate $(1: 1)$. Pellet was re-suspended in $0.6 \mathrm{ml}$ guanidine solution and allowed to dissolve for $15 \mathrm{~min}$ at $37^{\circ} \mathrm{C}$. Insoluble material was removed by centrifugation. Carbonyl concentration was measured at $370 \mathrm{~nm}$ using extinction coefficient $22000 \mathrm{M}^{-1} \mathrm{~cm}^{-1}$ and the results were expressed as $\mathrm{nM}$ of carbonyl/mg protein.

\subsubsection{Nitric oxide (NO)}

Nitric oxide was estimated by the method of Raddassie [40]. $100 \mu \mathrm{l}$ of sample and $100 \mu \mathrm{l}$ of Griess reagent were added in the wells of the ELISA strip. It was incubated for $30 \mathrm{~min}$ in dark at room temperature. Thereafter absorbance was read at $540 \mathrm{~nm}$ on ELISA reader. Nitric oxide concentration was determined by plotting a linear standard curve for sodium nitrate with a concentration range of $2.5-20 \mathrm{mM}$. The result was expressed as $\mu \mathrm{M}$ of $\mathrm{NO}_{2} / \mathrm{mg}$ protein accumulated in the sample.

\subsubsection{Citrulline}

Citrulline was estimated by the method of Boyde and Rahmatullah [41]. $40 \mu \mathrm{l}$ of sample was added to the $50 \mu 1$ of $30 \% \mathrm{ZnSO}_{4}$ mixed well and then centrifuged at $2000 \mathrm{rpm}$ for $10 \mathrm{~min}$. 40 $\mu l$ of the supernatant was mixed with $460 \mu \mathrm{l} 0.1$ $\mathrm{N} \mathrm{HCl}$ and $1.5 \mathrm{ml}$ freshly prepared chromogenic solution. It was boiled in water bath for $5 \mathrm{~min}$ at $100^{\circ} \mathrm{C}$ and absorbance was measured at $530 \mathrm{~nm}$. The result was expressed as $\mu \mathrm{M}$ of citrulline/mg protein.

\subsection{Antioxidant defense system}

\subsubsection{Catalase}

The catalase activity was estimated by measuring the breakdown of hydrogen peroxide at $240 \mathrm{~nm}$ according to the method of Luck [42]. The catalase activity was expressed as $\mathrm{mM}$ of $\mathrm{H}_{2} \mathrm{O}_{2} \mathrm{used} / \mathrm{min} / \mathrm{mg}$ of protein.

\subsubsection{Superoxide dismutase}

Superoxide dismutase activity was estimated by the method of Kono [43] which is based on the reduction of nitrobluetetrazolium mediated by superoxide anions (generated by photo-oxidation of hydroxylamine) to form formazan at $560 \mathrm{~nm}$. The activity of superoxide dismutase was expressed as International Units per $\mathrm{mg}$ protein (IU/mg protein) where $1 \mathrm{IU}$ is defined as the amount of enzyme inhibiting the increase in optical density by $50 \%$.

\subsubsection{Reduced glutathione (GSH)}

GSH was estimated as the total non-protein sulfhydryl groups by the method described by Moron [44]. In this method 5,5'-disthiobis-(2nitrobenzoic acid) (DTNB) is reduced by the $-\mathrm{SH}$ groups of GSH to form one mole of 2-nitro-5mercaptobenzoic acid per mole of $-\mathrm{SH}$. The nitromercaptobenzoic acid anion released has an intense yellow color, which can be used to measure $-\mathrm{SH}$ groups at $412 \mathrm{~nm}$. $10 \%$ 
homogenates in phosphate buffer were precipitated with $100 \mu \mathrm{l}$ of $25 \%$ TCA and the precipitate was removed by centrifugation at $1500 \mathrm{~g}$ for 10 minutes. $200 \mu \mathrm{l}$ of the supernatant was added to $800 \mu \mathrm{l}$ of phosphate buffer to which $2 \mathrm{ml}$ of DTNB (0.6 mM prepared in $0.2 \mathrm{M}$ phosphate buffer) was added. The absorbance of yellow color complex was read at $412 \mathrm{~nm}$. GSH was used as a standard to calculate the content of $\mathrm{GSH}$ which is expressed as $\mu \mathrm{M}$ of $\mathrm{GSH} / \mathrm{mg}$ of protein.

\subsection{Western blots}

Immunoblots for tyrosine hydroxylase and HSP70 were performed following the protocols of Thakur and Sanyal [45]. Mid brain region was used to prepare the $20 \%$ homogenate in the lysis buffer and centrifuged at 10,000 rpm for $30 \mathrm{~min}$. The resulting supernatants were collected for the protein estimation and analyzing the expressions of HSP-70 (Santa Cruze, 1:1000). 50 $\mu \mathrm{g}$ of protein were resolved on $10 \%$ SDS gel (SDSPAGE) and transferred on to nitrocellulose membrane. The blots were also performed with beta-actin antibody (Sigma Chemicals, St. Louis, MO, 1:5000) to ensure uniform protein loading.

\subsection{Histological analysis}

Histological analysis of mid-brain sections was done with hematoxylin and eosin staining [46]. Brain tissue was fixed in formaldehyde and embedded in paraffin wax [45]. Coronal sections of $5 \mu \mathrm{m}$ thickness were cut and picked over albumin coated slides. Sections were then stained with hematoxylin and eosin using standard procedure. Slides were cleared in xylene and finally mounted in DPX.

\subsection{Statistical analysis}

The results were expressed as mean \pm S.D. and were analyzed with the help of SPSSv14 computer software. One way analysis of variance (ANOVA) followed by least significant difference (LSD) post hoc analysis was applied to the results. For behavioral test, a multivariate ANOVA with LSD post hoc analysis was applied. A p-value less than or equal to 0.05 was considered to be statistically significant.

\section{Results}

\subsection{Behavioral analysis}

\subsubsection{Total locomotor activity}

A significant decrease $(\mathrm{p}<0.05)$ in the total locomotor activity of MG-132 treated group was observed in comparison to the control group at $2^{\text {nd }}, 8^{\text {th }}$ and $11^{\text {th }}$ day of the experimental study. However, post-treatment of $\mathrm{Cbx}$ resulted in a significant improvement $(\mathrm{p}<0.05)$ in the total locomotor activity in comparison to the animals treated with MG-132 (Fig. 1.A).

\subsubsection{Rota-rod test}

MG-132 administration was able to induce any significant decline $(\mathrm{p}<0.05)$ in the rota-rod score as compared to the control at $8^{\text {th }}$ and $11^{\text {th }}$ day of the study (Fig. 1.B). However, at $11^{\text {th }}$ day of study a significant increase $(\mathrm{p}<0.05)$ was observed in rota-rod score after $\mathrm{Cbx}$ posttreatment when compared to MG-132 group. It was noteworthy that all the surgically treated animals (including control) had a significantly lower rotarod score 2 days post-surgery in comparison to the $\mathrm{Cbx}$ group where no surgery was done. This observation indicates that surgery itself has some effects in the motor performance of animals. However, as the animals recovered with time, the rotarod score was comparable across various groups.

\subsubsection{Catalepsy (Bar Test)}

There was a significant increase $(\mathrm{p}<0.05)$ in the rigidity as indicated by catalepsy score in MG-132 treated group when compared to control group (Fig. 1.C). Prominent effects were observed 8 days after the MG-132 administration and approximately seven-fold increase was seen in cataleptic score at the $11^{\text {th }}$ day. However, Cbx post-treatment significantly inhibited the increase $(\mathrm{p}<0.05)$ in the cataleptic behavior in comparison to the MG-132 group at the $11^{\text {th }}$ day of the experiment (Fig. 1.C). 

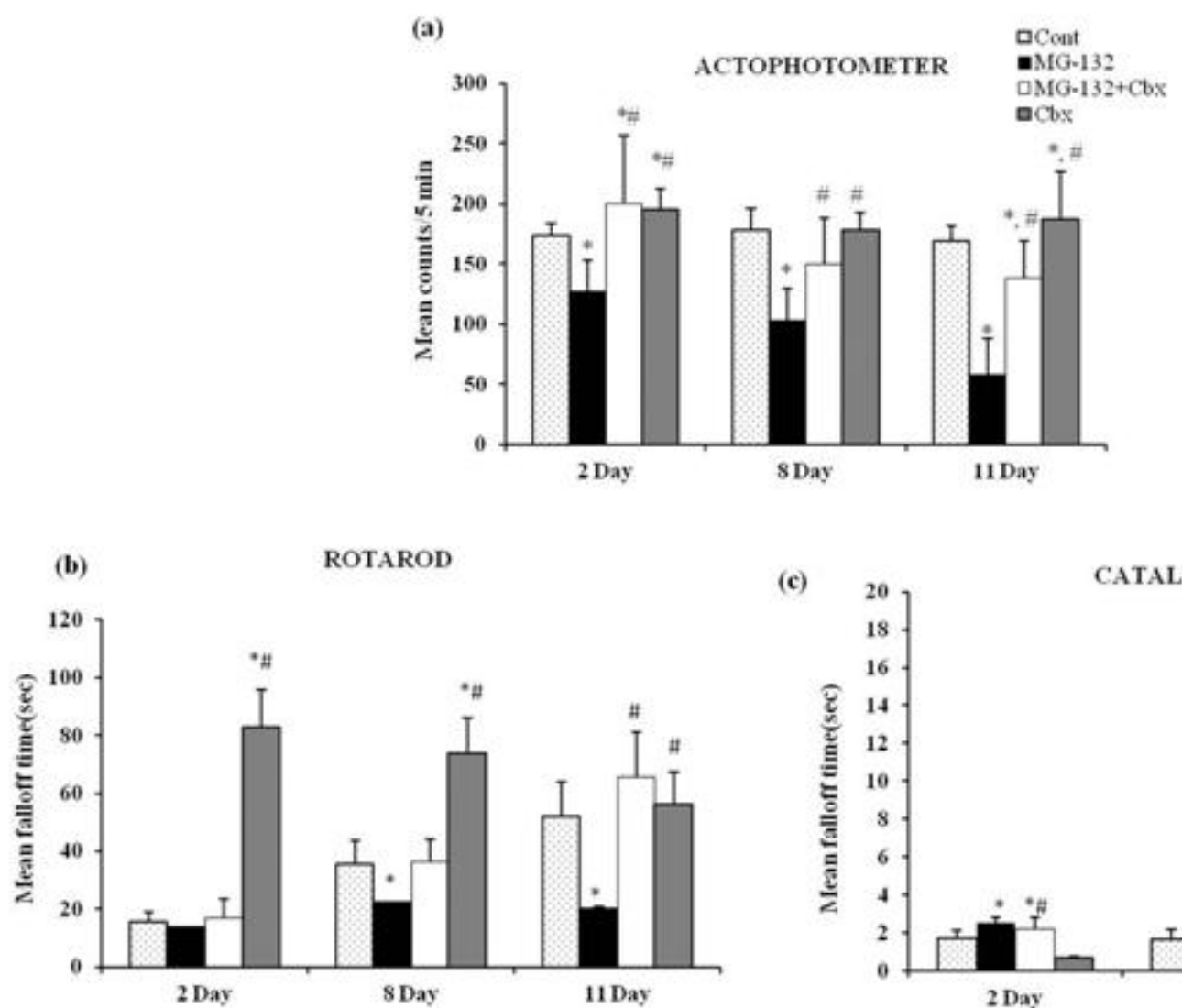

(c)

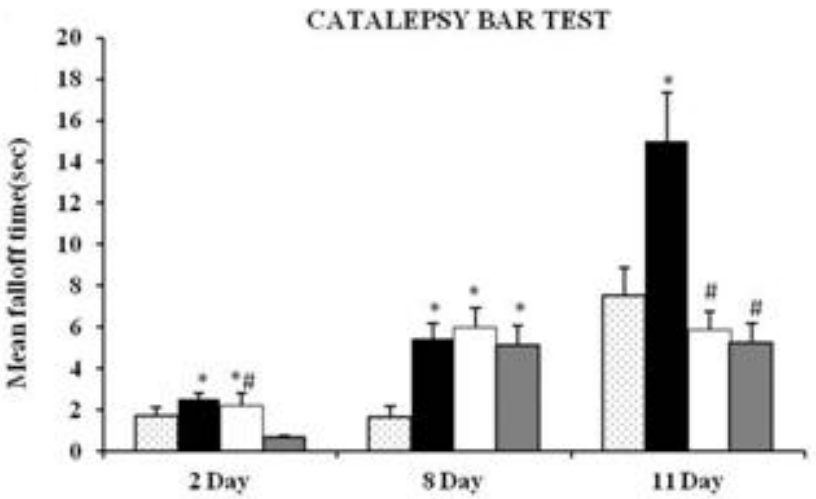

Figure 1 - Effect of various drug treatments on motor functions of animals

Effect of MG-132, MG-132+Cbx and Cbx on (A) Total locomotor activity (using actophotometer) (B) muscle relaxant activity (rota-rod test) and (C) Cataleptic behavioural (bar test) of rats. Values are Mean \pm S.D. of 6 animals. ${ }^{*}$ p $<0.05$

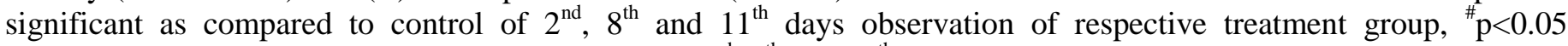
significant as compared to MG-132 treated group of $2^{\text {nd }}, 8^{\text {th }}$ and $11^{\text {th }}$ days observation of respective treatment group.

\subsection{Neurotransmitter Analysis}

MG-132 administration resulted in a significant decrease $(\mathrm{p}<0.01)$ in the dopamine levels as compared to the control counterpart (Fig. 2.A). However, Cbx post-treatment was able to prevent this decline and significantly higher levels of dopamine $(\mathrm{p}<0.001)$ were observed as compared to MG-132 group. In addition, a significant decrease $(\mathrm{p}<0.01)$ in the DOPAC levels (Fig. 2.C) along with a significant increase $(p<0.001)$ in the HVA levels (Fig. 2.B) was observed in MG-132 treated animals when compared to the control group. On the other hand, Cbx post-treatment showed significantly decreased $(\mathrm{p}<0.05)$ HVA levels and significantly increased $(\mathrm{p}<0.01)$ DOPAC levels in comparison to the MG-132 treated group. However, Cbx alone treatment showed significant increase $(\mathrm{p}<0.001)$ in dopamine levels compared to MG132 animals. In addition, a significant decrease $(p<0.05)$ in the HVA levels and a significant increase $(\mathrm{p}<0.01)$ in DOPAC levels of Cbx alone treated group was seen when compared to the MG-132 treated group. Overall, MG-132 treated group exhibited significantly higher $(\mathrm{p}<0.01)$ dopamine turnover when compared to sham group (Fig. 2.D). Similarly, Cbx post-treated $(\mathrm{p}<0.01)$ and $\mathrm{Cbx}$ alone $(\mathrm{p}<0.001)$ treated group showed lower rate of dopamine turnover when compared to MG-132 group.

\subsection{Histopathological analysis and Tyrosine Hydroxylase (TH)}

Histopathological examinations were performed in hematoxylin and eosin stained section in which cell shrinkage and degeneration 
of neurons in SN of mid brain region of MG-132 treated group was revealed (Fig. 3.A). A significant reduction $(p<0.001)$ in the number of neurons was clearly seen in the MG-132 treated animals as compared to the control (Fig. 3.B). However, Cbx post-treatment significantly prevented $(p<0.001)$ the loss of neurons in the group as compaered to the animals treated with MG-132. To confirm the loss of dopaminergic neurons western blot for $\mathrm{TH}$ was also done. It was found to be significantly reduced $(\mathrm{p}<0.001)$ in MG-132 treated group as compared to sham (Fig. 3.C). Whereas Cbx post-treatment and Cbx alone treatment led to significant increase $(\mathrm{p}<0.001)$ in the expression of $\mathrm{TH}$ when compared to the MG-132 treated group.
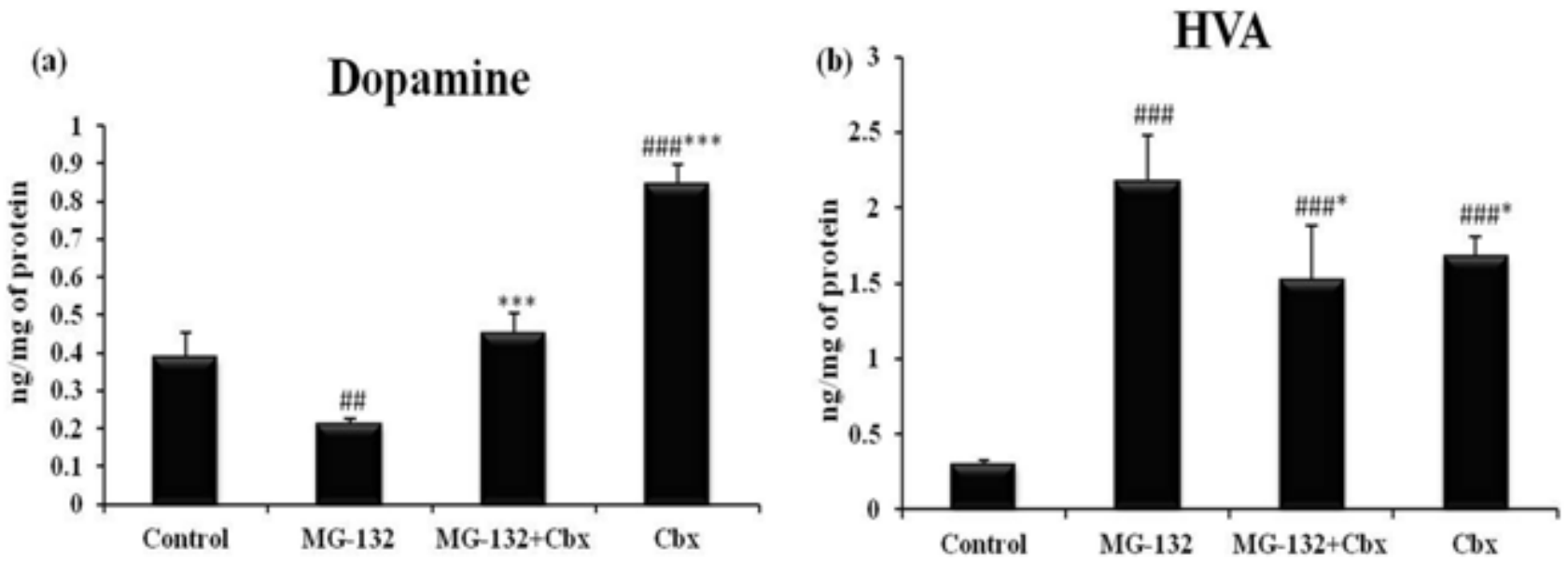

(c)

(d)

Dopamine Turnover

(DOPAC+HVA/Dopamine)

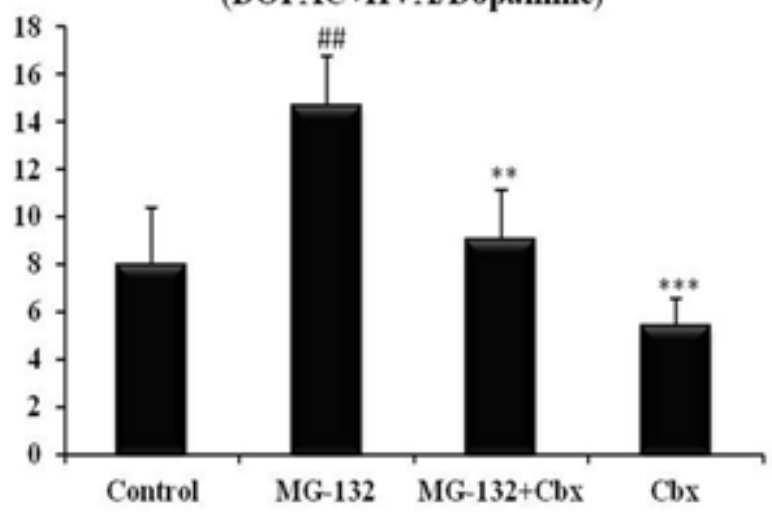

Figure 2 - Alterations in the dopamine metabolism following various drug treatments

Effect of MG-132, Cbx post-treatment and Cbx alone treatment on levels of (A) Dopamine (B) Homovanilic acid (HVA) (C) DOPAC and (D) Dopamine turnover (HVA+DOPAC/Dopamine). Values are Mean \pm S.D. of 6 animals. $\# \mathrm{p}<0.05,{ }^{\#} \mathrm{p}<0.01,{ }^{\# \#} \mathrm{p}<0.001$ significance when compared to sham; $* \mathrm{p}<0.05, * * \mathrm{p}<0.01, * * * \mathrm{p}<0.001$ significance when compared with MG-132 treated group. 
(a)

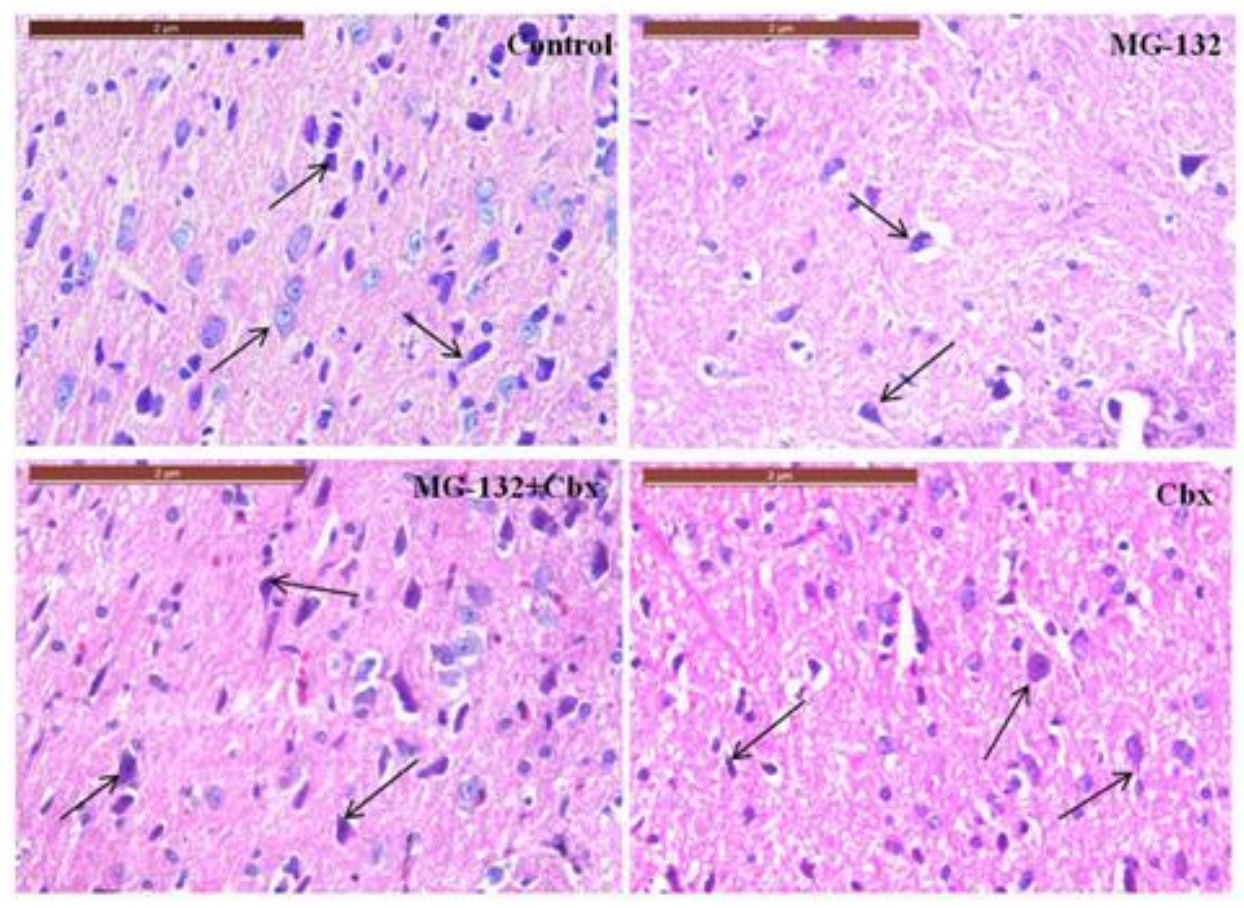

(b)

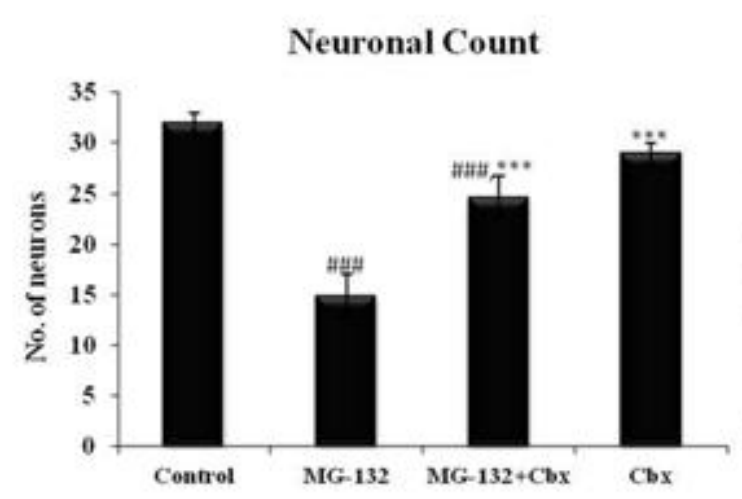

(c)

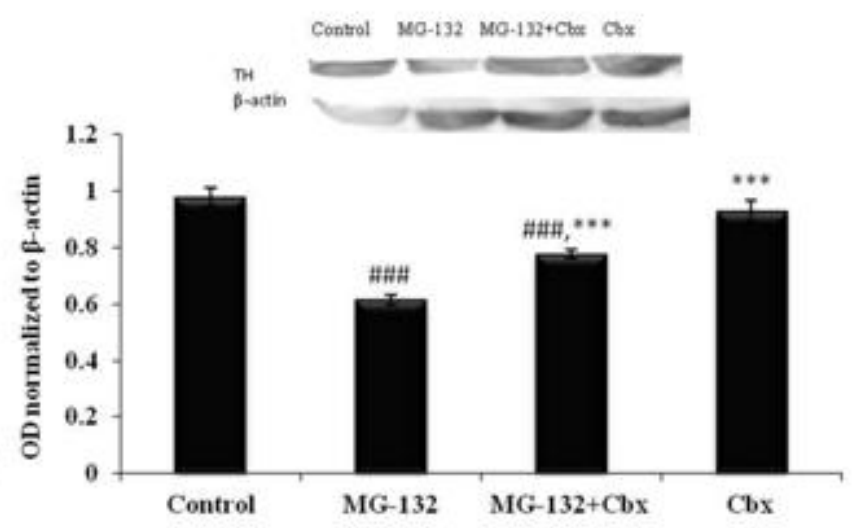

Figure 3 - Changes in the dopaminergic neurons and tyrosine hydroxylase following drug treatments

(A) Histological analysis of cells in the substantia nigra region reveals loss of neurons after MG-132 treatment, which was restored following Cbx. (B) Alteration in the neuronal count in the substantia nigra region after MG-132 and Cbx treatment. (C) Western blot analysis of tyrosine hydroxylase (TH) in the mid brain of rats in the indicated treatment groups, also shows similar results. Values are Mean \pm S.D. of 3 animals. ${ }^{\#} \mathrm{p}<0.05,{ }^{{ }^{\prime \prime}} \mathrm{p}<0.01,{ }^{\# \#} \mathrm{p}<0.001$ significance when groups compared to sham, $* \mathrm{p}<0.05, * * \mathrm{p}<0.01, * * * \mathrm{p}<0.001$ significance when groups compared to MG-132 treated group.

\subsection{Oxidative stress markers}

\subsubsection{LPO and protein carbonyl}

Lipid peroxidation and protein carbonyl are the two oxidative stress markers. They indicate the altered levels of the reactive oxygen species in the cellular environment. Levels of MDA (malondialdehyde) in MG-132 treated group was found to be significantly increased $(\mathrm{p}<0.001)$ when compared to sham (Fig. 4.A). On the other hand, Cbx supplementation significantly reduced $(\mathrm{p}<0.001)$ the MDA levels in comparison to the MG-132 treated animals. Protein carbonyl levels were also significantly high $(\mathrm{p}<0.001)$ in the MG132 group with respect to sham (Fig. 4.B). However, Cbx post-treatment aided in reducing 
$(p<0.001)$ the protein carbonyl levels significantly when a comparison was drawn with the MG-132 group.

\subsubsection{NO and citrulline}

A significant increase $(\mathrm{p}<0.001)$ in the levels of the nitric oxide (NO) was observed in MG-132 treated group when compared to the sham (Fig. 4.C). These levels were significantly

(a)

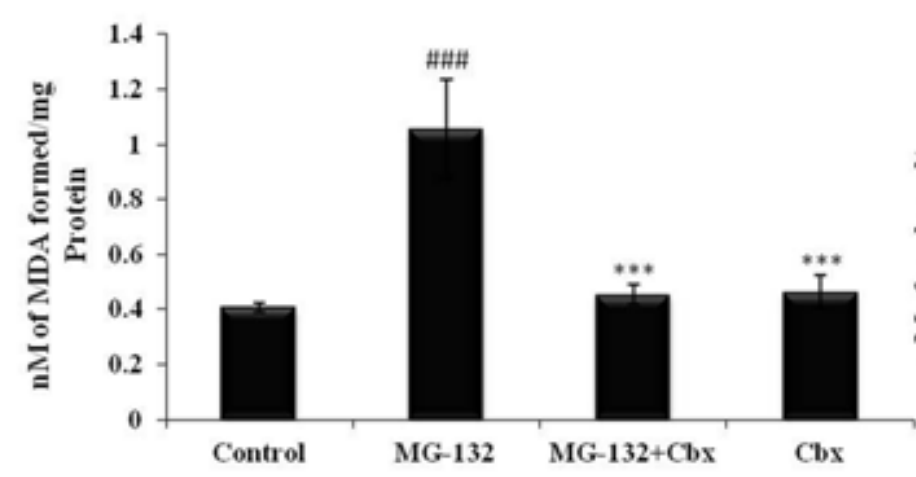

(b)

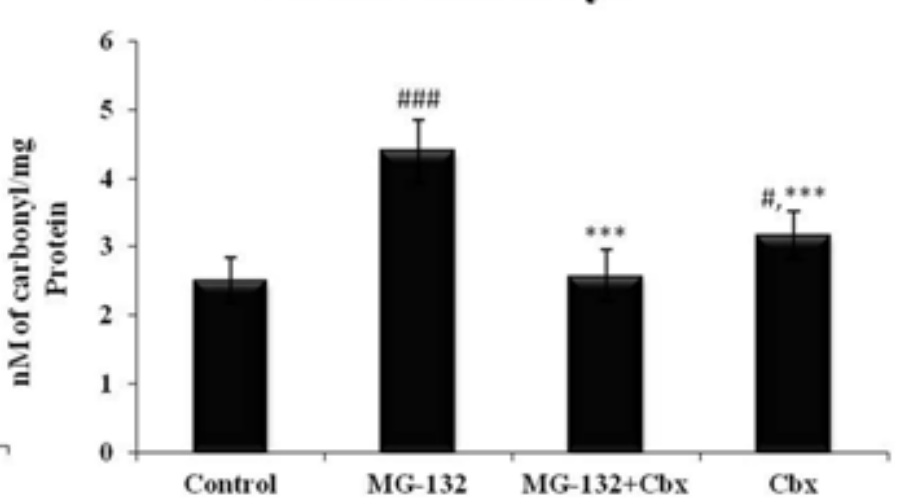

Protein Carbonyl
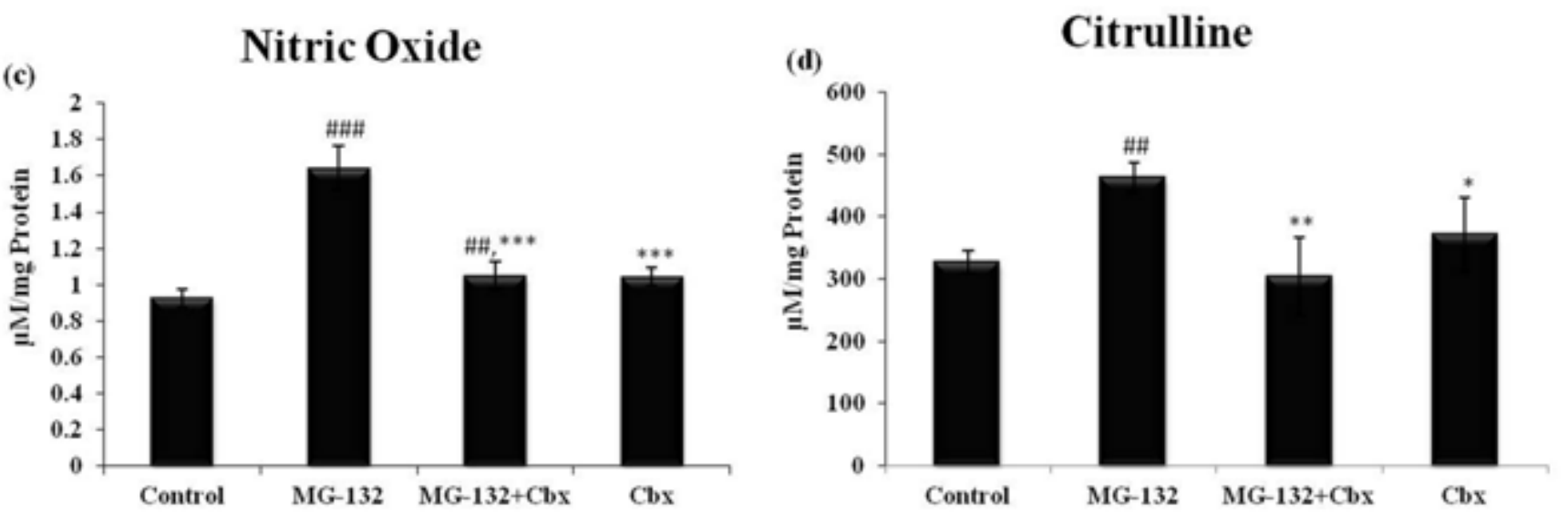

lowered $(p<0.001)$ in the Cbx post-treated animals as compared to the animals treated with MG-132. Also, a significant increase $(p<0.01)$ in the citrulline levels was observed in the MG-132 treated when compared to the sham (Fig.4.D) whereas in animals subjected to the Cbx posttreatment a remarkable significant decrease $(\mathrm{p}<0.01)$ was observed in the levels of citrulline in comparison to MG-132 treated group.

Figure 4 - Alteration in oxidative stress parameters upon drug treatments

Effect of MG-132, Cbx post-treatment and Cbx alone treatment on levels of (A) Lipid peroxidase (LPO) and (B) Protein carbonyl, (C) Nitric oxide (NO) and (D) Citrulline in mid brain of rats. Values are Mean \pm S.D. of 6 animals. $\# p<0.05, \# \# p<0.01, \# \#$, $<0.001$ significance when compared to sham, $* p<0.05, * * p<0.01, * * * p<0.001$ significance when compared to MG-132 treated group.

\subsection{Antioxidant defence enzymes}

\subsubsection{SOD and catalase}

The $\mathrm{Cu} / \mathrm{Zn}$-SOD activity was significantly increased $(\mathrm{p}<0.001)$ in MG-132 treated group as compared to sham (Fig. 5.B). However, Cbx post-treated and $\mathrm{Cbx}$ alone treated groups demonstrated significantly lowered $(p<0.001)$ $\mathrm{Cu} / \mathrm{Zn}$-SOD activity when compared to the MG132 treated group. In addition, catalase activity was found to be increased $(\mathrm{p}<0.001)$ significantly in MG-132 treated group in contrast to the sham 
(Fig. 5.A). Whereas in the case of animals receiving $\mathrm{Cbx}$ post-treatment and $\mathrm{Cbx}$ alone treatment a significant decrease $(\mathrm{p}<0.001)$ in the catalase activity in comparison to the MG-132 treated group was observed.

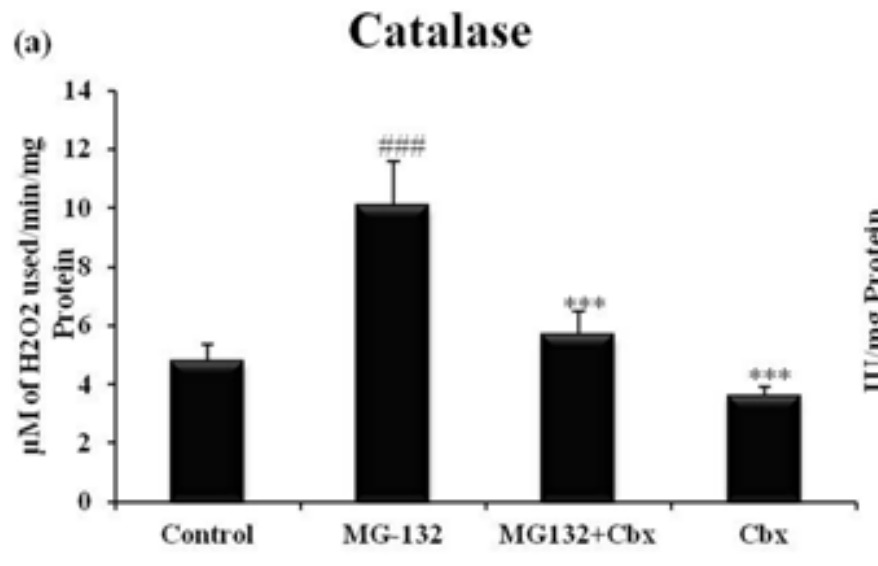

(b)

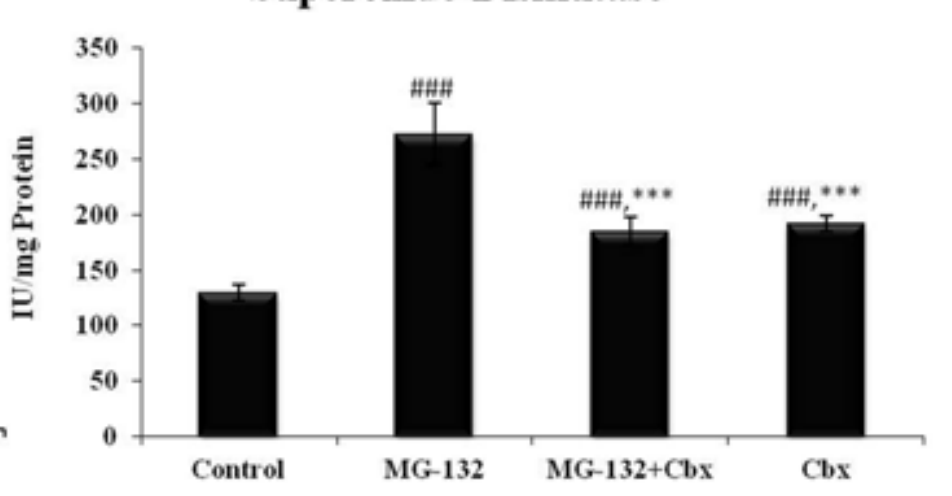

Figure 5 - Effect of drug treatments on the anti-oxidant enzymes

Effect of MG-132, Cbx post-treatment and Cbx alone treatment on levels of (A) Catalase and (B) Superoxide dismutase (SOD) in mid brain of rats. Values are Mean \pm S.D. of 6 animals. ${ }^{\#}<<0.05,{ }^{\#} p<0.01,{ }^{\#} p<0.001$ significance when compared to sham, ${ }^{*} \mathrm{p}<0.05, * * \mathrm{p}<0.01, * * * \mathrm{p}<0.001$ significance when compared to MG-132 treated group.

\section{GSH}

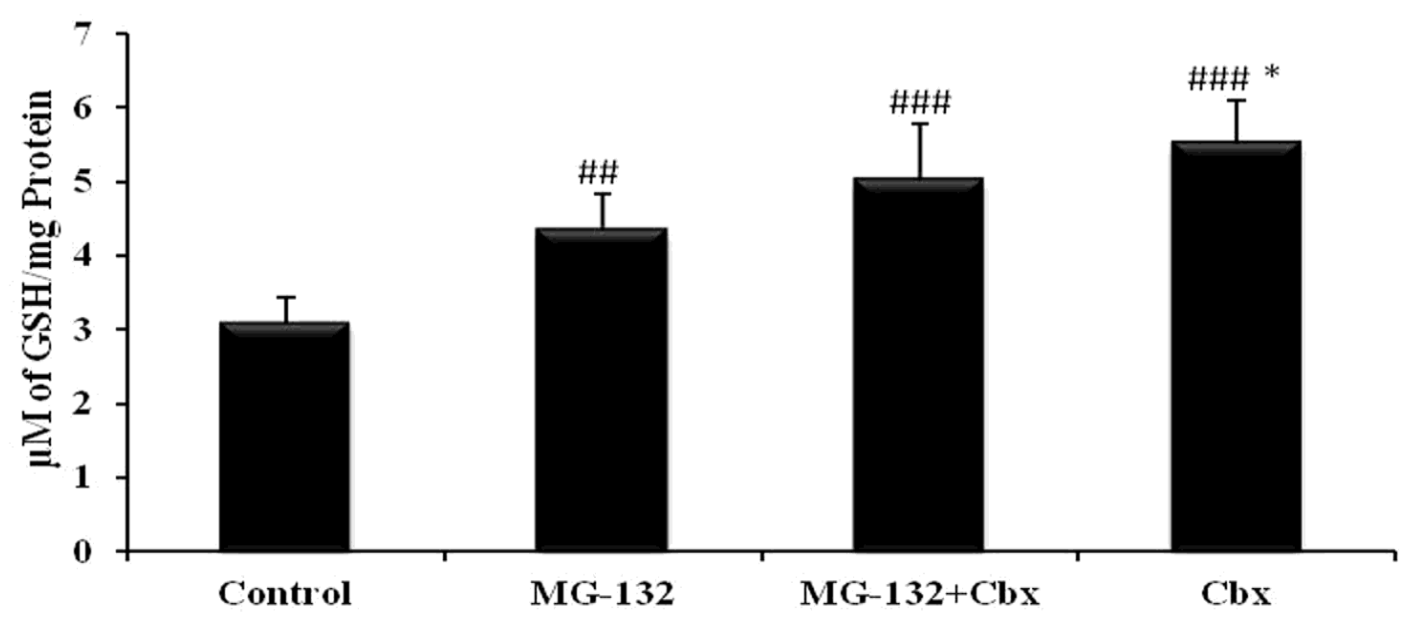

Figure 6 - Alterations in glutathione homeostasis following various drug treatments

Effect of MG-132, Cbx post-treatment and Cbx alone treatment on levels of GSH in mid brain of rats. Values are Mean \pm S.D. of 6 animals. ${ }^{\#}<<0.05,{ }^{\#} \mathrm{p}<0.01,{ }^{\# \#} \mathrm{p}<0.001$ significance when compared to sham, ${ }^{*} \mathrm{p}<0.05,{ }^{* *} \mathrm{p}<0.01$, $* * * \mathrm{p}<0.001$ significance when compared to MG-132 treated group.

\subsubsection{Reduced Glutathione}

GSH levels were found to be significantly increased $(\mathrm{p}<0.01)$ in the MG-132 treated group in comparison to the sham (Fig. 6). Similar results were exhibited by the $\mathrm{Cbx}$ post-treated and $\mathrm{Cbx}$ alone treated groups when compared to the sham. However, a significant increase $(\mathrm{p}<0.05)$ in the levels of GSH in case of $\mathrm{Cbx}$ alone treated group was observed when compared to the MG-132 treated group (Fig. 6). 


\subsection{HSP-70}

The expression of heat shock protein-70 (HSP-70) was significantly increased $(\mathrm{p}<0.001)$ in the MG-132 treated group as compared to sham (Fig. 7). Whereas Cbx post-treatment and alone $\mathrm{Cbx}$ treatment significantly increased $(\mathrm{p}<0.01, \mathrm{p}<0.001)$ the expression of HSP-70 when compared to the MG-132 treated group respectively.

\section{HSP-70}
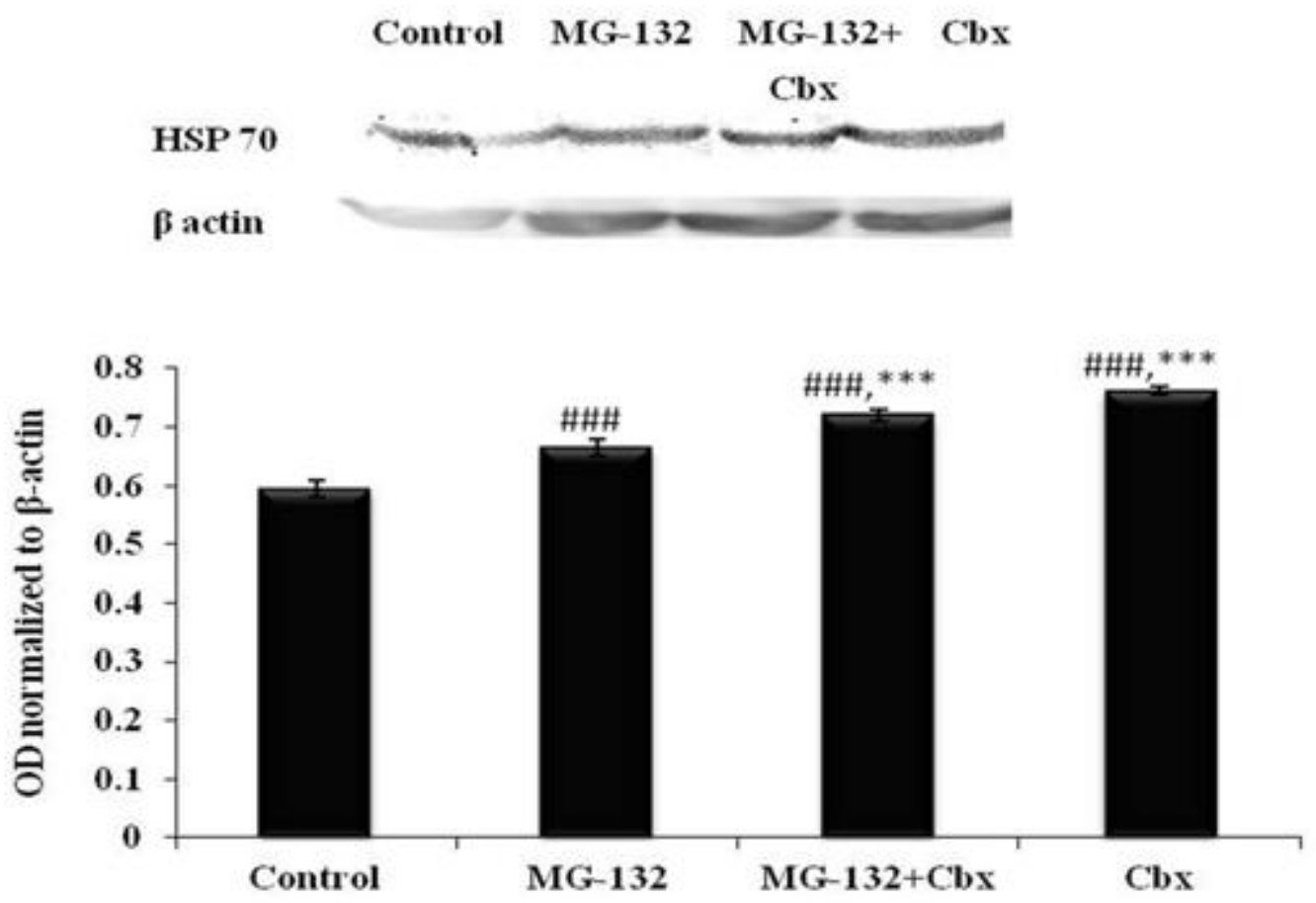

Figure 7 - HSP-70 upregulation following Cbx administration

Western blot analysis of HSP 70 expression in mid brain of rats in indicated treatment groups. Values are Mean \pm S.D. of 3 animals. ${ }^{\#} \mathrm{p}<0.05,{ }^{\#} \mathrm{p}<0.01,{ }^{\# \#} \mathrm{p}<0.001$ significance when compared to sham, ${ }^{*} \mathrm{p}<0.05, * * \mathrm{p}<0.01, * * * \mathrm{p}<0.001$ significance when compared to MG-132 treated group.

\section{Discussion}

Protein misfolding and aggregation is a common pathological characteristic feature of large number of neurodegenerative diseases such as Alzheimer's, Huntington's, and PD. Stimulation of HSP expression has been projected to be beneficial in these disorders due to their ability to assist in the refolding of aberrant proteins [47]. Recently, Cbx has been reported as a HSP inducer in the in-vitro studies [48-49, 26]. These HSP inducing effects were also confirmed in our previous in vivo studies [50]. By the virtue of HSP induction, Cbx has shown to exert neuroprotection in protein aggregation associated with PD both in vivo [50] and in vitro [49]. Thereby, we evaluated its potential protective role in the PD model that operates through the inhibition of proteasome system. The PD model was established by intranigral injection of proteasome inhibitor MG132 that has previously been reported to induce dopaminergic degeneration in the rat brain [51]. Cbx administration at the dose of $20 \mathrm{mg} / \mathrm{kg}$ body weight has shown to enhance the expression of various HSPs and subsequently improve the proteasome activity in a rotenone model of PD [50]. Thus, we speculated that it might show neuroprotective effects in the MG-132-based PD model. 
A single intranigral injection of MG-132 was able to produce relevant motor dysfunctions that are considered as trademark of PD. Catalepsy, which is a measure of akinesia [52] and immobility [53] was found to increase sharply after MG-132 administration. Further, a substantial decline in the total locomotor activity was also observed in the MG-132 treated group. In addition to catalepsy and total locomotor activity, rotarod test showed a significant decline in the score as compared to sham. Thus, MG-132 induced the akinesia, bradykinesia, rigidity in the animals and motor imbalance in the 12 day duration. The motor dysfunctions arise due to the significant decrease in the dopamine levels, which is the gold hallmark of PD [54]. This depletion of dopamine is an indicator of the loss of dopaminergic neurons.

Cbx post-treatment exhibited a significant improvement in the cataleptic score and total locomotor activity in comparison to MG-132 group. However, improvement was observed in the rotarod score at the later stage of the experiment. In fact, all the groups which underwent surgery (sham, MG-132, and conjunctive group) showed a decline in the rotarod score, which might be due to the effect of the surgery on the animals. Cbx treatment was able to prevent the loss of dopaminergic neurons as demonstrated by a significant increase in the levels of dopamine and $\mathrm{TH}$ in Cbx post-treatment group when compared to the MG-132 treated group. Thus, results indicate that $\mathrm{Cbx}$ has potency to prevent the degeneration of dopaminergic neurons caused due to the attack of proteasome inhibitor.

Earlier studies from our lab, demonstrated the ability of $\mathrm{Cbx}$ to inhibit the oxidative stress caused by rotenone treatment [50]. Proteasome inhibitors are known to evoke the conditions of oxidative stress [55]. Proteasome inhibitors lactacystin and epoxymicin have been shown to cause increase in protein carbonylation, 7hydroxyguanine, and NO production thus contributing to oxidative stress [56]. This effect is achieved by affecting several processes such as invoking neuroinflammation [55], stimulation of NOS [56] and inhibition of mitochondrial processes or enzymes [57]. Hence, we carried out a detailed study of various markers of oxidative stress as well as antioxidant defenses in the cells to decipher the putative mechanism by which Cbx operates in the MG-132 model.

The inhibition of proteasome results in the reduced clearance of oxidative damaged proteins as evidenced by the increase in the protein carbonyl levels. Concomitantly, an increase in the oxidative damage to lipids was observed in the MG-132 injected animals. Various antioxidant defenses such as GSH, SOD and catalase also get activated in response to the oxidative stress. Increase in the catalase activity observed after MG-132 injection could be due to the excessive production of $\mathrm{H}_{2} \mathrm{O}_{2}$ [58] while the changes in the SOD activity could be due to the short-term cell response to free radical insult [59]. Along with these changes, the GSH levels were also observed to increase, which might be an adaptive response to increased free radical rush. In addition, activation of iNOS expression as evidenced by the upsurge in the levels of $\mathrm{NO}$ and citrulline levels was also observed following MG-132 injection. Prolonged and excessive oxidative stress results in the death of neurons by apoptosis [60]. This was well reflected by a decrease in the cell count in substania nigra region of the MG132 treated animals.

The Cbx post-treatment was able to reduce the oxidative stress conditions as evident by the decrease in the levels of lipid peroxidation and protein carbonylation products. In addition, increase in the levels of GSH were also observed, which helped in the scavenging of free radicals. $\mathrm{Cbx}$ is also known to activate the expression of various cytoprotective HSPs. The decrease in the oxidative stress that was observed following $\mathrm{Cbx}$ post-treatment might be due to the HSP-70 induction by $\mathrm{Cbx}$. HSP-70 has been reported to inhibit the iNOS expression and subsequently reduce the NO production [61-62]. Thus, reduced NO levels might be helping to curb the conditions of oxidative stress. Though an adaptive increase in the HSP-70 was also observed in MG-132 treated animals, the levels were insufficient to prevent the cell death as indicated by loss of dopamine. However, the even higher expression of HSP-70 in the Cbx post-treated group was able 
to rescue the cells effectively against oxidative stress.

Thus, Cbx offers neuroprotection in the MG132 induced toxicity. This protection is possibly mediated by its known activation of cytoprotective HSPs. These HSPs help to combat oxidative stress and inhibits apoptosis. The effects of $\mathrm{Cbx}$ should be explored further to elucidate the molecular pathways involved in its neuroprotective actions.

\section{Acknowledgement}

The studied was carried out with the funds received from Department of Science and Technology (DST).

\section{References}

1. Morgante, L.; Salemi, G.; Meneghini, F.; Di Rosa, A. E.; Epifanio, A.; Grigoletto, F.; Ragonese, P.; Patti, F.; Reggio, A.; Di Perri, R.; Savettieri, G. Parkinson Disease Survival A Population-Based Study, Arch Neurol, 2000, 57(4), 507-12. DOI: 10.1001/archneur.57.4.507

2. Levy, G.; Tang, M. X.; Louis, E. D.; Côté, L. J.; Alfaro, B.; Mejia, H.; Stern, Y.; Marder, $\mathrm{K}$. The association of incident dementia with mortality in PD, Neurology, 2002, 59, 170813. DOI:10.1212/01.WNL.0000036610.36834.E0

3. Dauer, W.; Przedborski, S. Parkinson's Disease: Mechanisms and Models, Neuron, 2003, 39, 889-909. DOI: 10.1016/S08966273(03)00568-3

4. Cookson, M. R. The biochemistry of Parkinson's disease. Annu Rev Biochem, 2005, 74, 29-52. DOI: 10.1146/annurev.biochem.74.082803.133400

5. Ali, Y. O.; Kitay, B. M.; Zhai, R. G. Dealing with Misfolded Proteins: Examining the Neuroprotective Role of Molecular Chaperones in Neurodegeneration, Molecules, 2011, 15(10), 6859-87. DOI: $\underline{10.3390 / \text { molecules } 15106859}$
6. Andersen, J. K. Oxidative stress in neurodegeneration: cause or consequence? Nat Med, 2004, 10 S, 18-25.

7. Fornai, F.; Schlüter, O. M.; Lenzi, P.; Gesi, M.; Ruffoli, $\quad$ R.; Ferrucci, M.; Lazzeri, G.; Busceti, C. L.; Pontarelli, F.; Battaglia, G.; Pellegrini, A.; Nicoletti, F.; Ruggieri, S.; Paparelli, A.; Südhof, T. C. Parkinson-like syndrome induced by continuous MPTP infusion: convergent roles of the Ubiquitin proteasome system and alpha-synuclein, Proc Natl Acad Sci. USA, 2005, 102, 3413-18. DOI: $10.1073 /$ pnas.0409713102

8. Glickman, M. H.; Ciechanover, A. The ubiquitin-proteasome proteolytic pathway: Destruction for the sake of construction, Physiol Rev, 2002, 82, 373-428.

9. Yi, J. J.; Ehlers, M. D. Emerging roles for ubiquitin and protein degradation in neuronal function, Pharmacol Rev, 2007, 59, 14-39. DOI: $10.1124 /$ pr.59.1.4

10. Malkus, K. A.; Tsika, E.; Ischiropoulos, H. Oxidative modifications, mitochondrial dysfunction, and impaired protein degradation in Parkinson's disease: how neurons are lost in the Bermuda triangle, Mol Neurodegener, 2009, 4, 24. DOI: 10.1186/1750-1326-4-24

11. Huang, Q.; Figueiredo-Pereira, M. E. Ubiquitin/proteasome pathway impairment in neurodegeneration: Therapeutic implications, Apoptosis, 2010, 15(11), 1292-1311. DOI: 10.1007/s10495-010-0466-Z

12. Muchowski, P. J.; Wacker, J. L. Modulation of neurodegeneration by molecular chaperones, Nat Rev Neurosci, 2005, 6, 1122. DOI: $\underline{10.1038 / \mathrm{nrn} 1587}$

13. Parsell, D. A.; Lindquist, S. The function of heat-shock proteins in stress tolerance: degradation and reactivation of damaged proteins, Ann Rev Genet, 1993, 27, 437-96. DOI: $10.1146 /$ annurev.ge.27.120193.002253

14. Hartl, F. U.; Hayer-Hartl, M. Molecular chaperones in the cytosol: from nascent chain to folded protein, Science, 2002, 295, 185258. DOI: $10.1126 /$ science. 1068408

15. Morimoto, R. I. Dynamic remodeling of transcription complexes by molecular chaperones, Cell, 2002, 110, 281-84. DOI: 10.1016/S00928674(02)00860-7 
16. Morimoto, R. I.; Santoro, M. G. Stressinducible responses and heat shock proteins: new pharmacologic targets for cytoprotection, Nat Biotechnol, 1998, 16, 833-38. DOI: 10.1038/nbt0998-833

17. Jäättelä, M. Heat shock proteins as cellular lifeguards, Ann Med, 1999, 31, 261-71. DOI: $\underline{10.3109 / 07853899908995889}$

18. Ohtsuka, K.; Hata, M. Molecular chaperone function of mammalian Hsp70 and Hsp40A review, Int J Hyperthermia, 2000, 16, 23145. DOI: $10.1080 / 026567300285259$

19. Ohtsuka, K.; Kawashima, D.; Gu, Y.; Saito, $\mathrm{K}$. Inducers and co-inducers of molecular chaperones, Int J Hyperthermia, 2005, 21, 703-11. DOI: 10.1080/02656730500384248

20. Sõti, C.; Nagy, E.; Giricz, Z.; Vígh, L.; Csermely, P.; Ferdinandy, P. Heat shock proteins as emerging therapeutic targets, $\mathrm{Br} J$ Pharmacol, 2005, 146, 769-80. DOI: 10.1038/sj.bjp.0706396

21. Westerheide, S. D.; Morimoto, R. I. Heat shock response modulators as therapeutic tools for diseases of protein conformation, $J$ Biol Chem, 2005, 280, 33097-100. DOI: $\underline{10.1074 / \mathrm{jbc} . \mathrm{R} 500010200}$

22. Hosseinzadeh, H.; Nassiri Asl, M. Anticonvulsant, sedative and muscle relaxant effects of carbenoxolone in mice, $B M C$ Pharmacol, 2003, 3, 3. DOI: 10.1186/14712210-3-3

23. Gareri, P.; Condorelli, D.; Belluardo, N.; Russo, E.; Loiacono, A.; Barresi, V.; Trovato-Salinaro, A.; Mirone, M. B.; Ferreri Ibbadu, G.; De Sarro, G. Anticonvulsant effects of carbenoxolone in genetically epilepsy prone rats (GEPRs), Neuropharmacology, 2004, 47, 1205-16. DOI: 10.1016/j.neuropharm.2004.08.021

24. de Pina-Benabou, M. H.; Szostak, V.; Kyrozis, A.; Rempe, D.; Uziel, D.; UrbanMaldonado, M.; Benabou, S.; Spray, D. C.; Federoff, H. J.; Stanton, P. K.; Rozental, $\mathrm{R}$. Blockade of gap junctions in vivo provides neuroprotection after perinatal global ischemia, Stroke, 2005, 36, 2232-37. DOI: 10.1161/01.STR.0000182239.75969.d8

25. Kampinga, H. H.; Hageman, J.; Vos, M. J.; Kubota, H; Tanguay, R. M.; Bruford, E.
A.; Cheetham, M. E.; Chen, B.; Hightower, L. E. Guidelines for the nomenclature of the human heat shock proteins, Cell Stress Chaperones, 2008, 14, 105-11. DOI: 10.1007/s12192-008-0068-7

26. Kawashima, D.; Asai, M.; Katagiri, K.; Takeuchi, R.; Ohtsuka, K. Reinvestigation of the effect of carbenoxolone on the induction of heat shock proteins, Cell Stress Chaperone, 2009, 14, 535-43. DOI: 10.1007/s12192-009-0106-0

27. Tsubuki, S.; Saito, Y.; Tomioka, M.; Ito, H.; Kawashima, S. Differential inhibition of calpain and proteasome activities by peptidyl aldehydes of di-leucine and tri-leucine, $J$ Biochem, 1996, 119, 572-76. DOI: 10.1093/oxfordjournals.jbchem.a021280

28. Galbiati, F.; Volonte, D.; Minetti, C.; Bregman, D. B.; Lisanti, M. P. Limbgirdle muscular dystrophy (LGMD-1C) mutants of caveolin-3 undergo ubiquitination and proteasomal degradation: treatment with proteasomal inhibitors blocks the dominant negative effect of LGMD-1C mutants and rescues wild-type caveolin-3, J Biol Chem, 2000, 275, 37702. DOI: 10.1074/jbc.M006657200

29. Lee, D. H.; Goldberg, A. L. Proteasome inhibitors: valuable new tools for cell biologists, Trends Cell Biol, 1998, 8, 397403. DOI: $10.1016 / \mathrm{S} 09628924(98) 01346-4$

30. Kisselev, A. F.; Goldberg, A. L. Preoteasome inhibitor: From research tools to drug candidates, Chem Biol, 2001, 8, 739-58. DOI: 10.1016/S10745521(01)00056-4

31. Fuertes, M. A.; Castilla, J.; Alonso, C.; Pérez, J. M. Biochemical modulation of cisplatin mechanism of action: from cytotoxicity to induction of cell death through interconnections between apoptotic and necrotic pathways, Curr Med Chem, 2003, 10, 257-66. DOI: $10.2174 / 0929867033368484$

32. Rodgers, K. J.; Dean, R. T. Assessment of proteasome activity in cell lysates and tissue homogenates using peptide substrates, Int J Biochem Cell Biol, 2003, 35(5), 716-27. DOI: $\underline{10.1016 / \mathrm{S} 13572725(02) 00391-6}$ 
33. Costall, B.; Naylor, R. J. On catalepsy and catatonia and the predictability of the catalepsy test for neuroleptic activity, Psycho pharmacologia, 1974, 34(3), 233-41. DOI: 10.1007/BF00421964

34. Bishnoi, M.; Chopra, K.; Kulkarni, S. K. Involvement of adenosinergic receptor system in an animal model of tardive dyskinesia and associated behavioural, biochemical and neurochemical changes, Eur J Pharmacol, 2006, 552, 55-66. DOI: 10.1016/j.ejphar.2006.09.010

35. Kulkarni, S. K. Handbook of experimental pharmacology. Vallabh Prakashan, Delhi, 1999.

36. Thakur, P.; Nehru, B. Anti-inflammatory properties rather than antioxidant capability is the major mechanism of neuroprotection by sodium salicylate in a chronic rotenone model of Parkinson's disease, Neuroscience, 2013a, 12, 420-31. DOI: 10.1016/j.neuroscience.2012.11.006

37. Nemzer, B. V.; Yashin, A. Y.; Yashin, Y. I. The Issues of Antioxidant Therapy, Am. J. Biomed. Sci, 2013, 5(2), 80-108. DOI: 10.5099/aj130200080

38. Wills, E. D. Mechanism of lipid peroxide formation in animal tissue, Biochem J, 1966, 99, 667-76.

39. Burcham, P. C. Modified protein carbonyl assay detects oxidized membrane proteins, a new tool for assessing drug- and chemicallyinduced oxidative cell injury, J Pharmacol Toxicol Methods, 2007, 56(1), 18-22. DOI: $\underline{\text { 10.1016/j.vascn.2006.02.015 }}$

40. Raddassi, K.; Berthon, B.; Petit, J. F.; Lemaire, G. Role of calcium in the activation of mouse peritoneal macrophages: induction of NO synthesis by calcium inophores and thapsigargin, Cellular Immunolog, 1993, 153, 443-55. DOI: 10.1006/cimm.1994.1041

41. Boyde, T. R.; Rahmatullah, M. Optimization of conditions for the colorimetric determination of Citrulline, using diacetylmonoxime, Analytical Biochem, 1980, 107, 424-31. DOI: $\underline{10.1016 / 00032697(80) 90404-2}$

42. Luck, H. A spectrophotometric method for the estimation of catalase. In: Methods of enzymatic analysis, Academic Press, New York, 1963, pp 886-87.

43. Kono, Y. Generation of superoxide radicals during auto oxidation of hydroxylamine and an assay for superoxide dismutase, Arch Biochem Biophys, 1978, 186, 189-95. DOI: $\underline{10.1016 / 00039861(78) 90479-4}$

44. Moron, M. S.; Depierre, J. W.; Mannervik, B. Levels of glutathione, glutathione reductase and glutathione-s-transferase activities in rat lung and liver, Biochem Biophys Acta, 1979, 562-67.

45. Thakur, P.; Sanyal, S. N. Chemopreventive Role of Preferential COX-2 Inhibitor Diclofenac in 9, 10Dimethybenz(a)anthracene Induced Experimental Lung Carcinogenesis, Am. J. Biomed. Sci, 2010, 2(3), 275-288. DOI: 10.5099/aj100300275

46. Humanson, G. L. Animal tissue technique. Beadle, G. W., Emerson, R., Whiteker,D. M., Ed.; W. H. Freeman and Publications, San Francisco, 1962; pp 3-126.

47. Aridon, P.; Geraci, F.; Turturici, G.; D'Amelio, M.; Savettieri, G.; Sconzo, G. Protective role of heat shock proteins in Parkinson's disease, Neurodegener Dis, 2011, 8, 155-68. DOI: $10.1159 / 000321548$

48. Nagayama, S.; Jono, H.; Suzaki, H.; Sakai, K.; Tsuruya, E.; Yamatsu, I.; Isohama, Y.; Miyata, T.; Kai, H. Carbenoxolone, a new inducer of heat shock protein 70, Life Sci, 2001, 69, 2867-73. DOI: 10.1016/S00243205(01)01362-5

49. Kilpatrick, K.; Novoa, J. A.; Hancock, T.; Guerriero, C. J.; Wipf, P.; Brodsky, J. L.; Segatori, L. Chemical Induction of Hsp70 Reduces $\alpha$-Synuclein Aggregation in Neuroglioma Cells, ACS Chem Biol, 2013. DOI: $10.1021 / \mathrm{cb} 400017 \mathrm{~h}$

50. Thakur, P.; Nehru, B. Long-term heat shock proteins (HSPs) induction by carbenoxolone improves hallmark features of Parkinson's disease in a rotenone-based model, Neuropharmacology, 2013b, 79, 190-200. DOI: $10.1016 /$ j.neuropharm.2013.11.016

51. Sun, F.; Anantharam, V.; Zhang, D.; Latchoumycandane, C.; Kanthasamy, A.; Kanthasamy, A. G. Proteasome Inhibitor 
MG-132 Induces Dopaminergic Degeneration in Cell Culture and Animal Models, Neurotoxicology, 2006, 27, 807-15. DOI: 10.1016/j.neuro.2006.06.006

52. Schrag, A.; Barone, P.; Brown, R. G.; Leentjens, A. F.; McDonald, W. M.; Starkstein, S.; Weintraub, D.; Poewe, W.; Rascol, O.; Sampaio, C.; Stebbins, G. T.; Goetz, C. G. Depression Rating Scales in Parkinson's Disease: Critique and Recommendations, Movement Disorders, 2007, 22(8), 1077-92. DOI: $10.1002 / \mathrm{mds} .21333$

53. Mahmoudi, J.; Mohajjel Nayebi, A.; Samini, M.; Reyhani-Rad, S.; Babapour, V. 5$\mathrm{HT}_{1 \mathrm{~A}}$ receptor activation improves anticataleptic effect of levodopa in 6hydroxydopamine-lesioned rats, Daru, 2011, 19, 338-43.

54. Wolters, E. C.; Francot, C. M. Mental dysfunction in Parkinson's disease, Parkinsonism Relat Disord, 1998, 4(3), 10712. DOI: $10.1016 / \mathrm{S} 13538020(98) 00022-4$

55. Halliwell, B. Oxidative stress and neurodegeneration: where are we now? $J$ Neurochem, 2006, 97(6), 1634-58. DOI: 10.1111/j.14714159.2006.03907.x

56. Lee, M. H.; Hyun, D. H.; Jenner, P.; Halliwell, B. Effect of proteasome inhibition on cellular oxidative damage, antioxidant defences and nitric oxide production, $J$ Neurochem, 2001, 78, 32-41. DOI: 10.1046/j.14714159.2001.00416.X

57. Sullivan, P. G.; Dragicevic, N. B.; Deng, J. H.; Bai, Y.; Dimayuga, E.; Ding, Q.; Chen, Q.; Bruce-Keller, A. J.; Keller, J. N. Proteasome inhibition alters neural mitochondrial homeostasis and mitochondria turnover, J Biol Chem, 2004, 279, 20699 707. DOI: $10.1074 / \mathrm{jbc} . \mathrm{M} 313579200$

58. Zoccarato, F.; Toscano, P.; Alexandre, A. Dopamine-derived dopaminochrome promotes $\mathrm{H} 2 \mathrm{O} 2$ release at mitochondrial complex I: stimulation by rotenone, control by $\mathrm{Ca} 2$, and relevance to Parkinson disease, $J$ Biol Chem, 2005, 280, 15587-94. DOI: 10.1074/jbc.M500657200

59. Nikam, S.; Nikam, P.; Ahaley, S. K.; Sontakke, A. V. Oxidative Stress in Parkinson's Disease, Indian Journal of Clinical Biochemistry, 2009, 24(1), 98-101. DOI: 10.1007/s12291-009-0017-y

60. Ratan, R. R.; Murphy, T. H.; Baraban, J. M. Oxidative stress induces apoptosis in embryonic cortical neurons, J Neurochem, 1994, 62(1), 376-79. DOI: 10.1046/j.14714159.1994.62010376.x

61. Matsuda, H.; Kagerura, T.; Toguchida, I.; Ueda, H.; Morikawa, T.; Yoshikawa, M. Inhibitory effects of sesquiterpenes from bay leaf on nitric oxide production in lipopolysaccharide-activated macrophages: structure requirement and role of heat shock protein induction, Life Sci, 2000, 66(22), 2151-57.

DOI: 10.1016/S00243205(00)00542-7

62. Dobbin, C. A.; Smith, N. C.; Johnson, A. M. Heat shock protein 70 is a potential virulence factor in murine toxoplasma infection via immunomodulation of host NF-kappa B and nitric oxide, J Immunol, 2002, 169(2), 95865. DOI: $10.4049 /$ jimmunol.169.2.958 